Włodzimierz Fehler

Uniwersytet Przyrodniczo-Humanistyczny w Siedlcach

Iryna Pavlenko

Uniwersytet Warszawski

\section{Vladimir Salli}

Narodowy Uniwersytet Techniczny Dnipro Politechnika

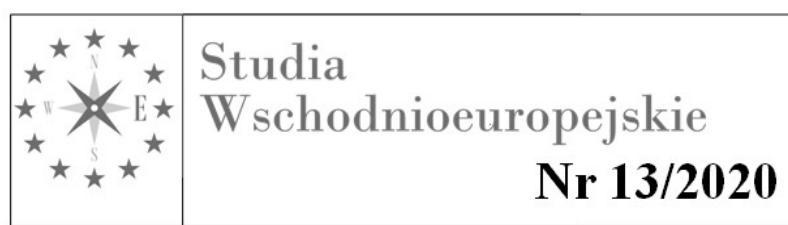

\title{
Energy stability in the context of modernization of post-soviet countries
}

$\mathrm{T}$

The subject of this article is the methodological and practical issues of ensuring the stable functioning of systems for eliminating the harmful effects of underground coal mining in the modernization of post-Soviet countries. Coal accounts for nearly a quarter of total EU electricity production. It is also an important economic factor, providing jobs for about 240,000 people in mines and power plants in 41 regions and 12 EU countries. While coal remains the central fuel in the European energy balance, a shift to cleaner forms of energy and innovative technologies such as carbon capture and storage is a prerequisite for fulfilling the EU's commitment to reduce $\mathrm{CO} 2$ emissions by at least $40 \%$ by 2030 . Phasing out coal is a constant reality in Europe. Since 2012, coal production has declined by almost a third ${ }^{17}$

In 2019, steam coal reserves in the ports of Rotterdam and Amsterdam increased to maximum levels, as coal consumption decreased due to natural gas prices falling. Gas has become a more attractive fuel for generating electricity for European utilities, and renewable energy sources, such as the sun andind exert pressure on coal. In addition, the European government actively supports the energy business that helps reduce emissions. Although the transition to a low-carbon economy offers many opportunities, the economic and social consequences in many coal regions should not be ignored - this is where the problems for coal regions with economies in transition begin ${ }^{18}$.

\footnotetext{
${ }^{17}$ Energy Efficiency Plan 2017, Impact Assessment Annex II. — Brussels: European Commission, March 8, 2017. - (Commission Staff Working Document)

${ }^{18}$ EU-Russian Energy Dialogue: The First Ten Years: 2000-2010/European Commission Directorate General for Energy. - Brussels, Belgium: European Union, 2011
} 
Coal substitution in the energy balance of Europe will continue in the coming years: according to the forecast of the International Energy Agency (IEA), the share of coal plants in European electricity generation will decrease from $23 \%$ in 2017 to $15 \%$ in 2025 and $10 \%$ in 2030; while the share of solar and wind will increase from $12 \%$ to $20 \%$ and $27 \%$, respectively, and gas - will not change much $(21 \%$ in 2017 against $20 \%$ in the 2025 th and 2030th). Coal generation was most severely reduced in Western European countries (for example, in Germany - by $22 \%$, in the UK - by 65\%, and in France - by 75\%), which in 2018 accounted for $95 \%$ of the introduction of capacities in alternative energy among $28 \mathrm{EU}$ states $^{19}$.

Available literature offers numerous mechanisms for determining the costeffectiveness of environmental protection measures of the POST-COAL systems and assessing the environmental damage that caused to the national economy by environmental pollution in modern conditions. However, they do not contribute to the successful environmental activities of enterprises, since the appropriate methods do not take into account the features that arose because of the transformation of the euro politics in terms of rejecting coal generation. In addition, countries need to calculate the effect of introducing environmental measures in which they are not directly related. Therefore, it is no coincidence that in determining the effectiveness of environmental protection activities in coal-mining countries, optimality criteria is used that do not characterize the period of environmental investments and do not reflect real terms for managing production flows. These concepts are reflected in the famous works of environmental economists I.Alexandrova, A.Amoshi, A.Astakhov, A.Bardas, I.Buzko, S.Bugay, V.Vishnevskogo, A.Voronkova V.Mishchenko, N.Nedodaeva, I.Petenko and others.

Currently, the environmental focus of energy supply planning in Europe is becoming increasingly important since the pressure on the environment of mining, metallurgical, fuel and energy and chemical complexes has reached limit values. This requires the adoption of effective measures to protect industrial regions, and these measures cannot be universal in the form of a specific set of sanctions or incentives. Underground mining of minerals generates very specific harmful manifestations and require completely different measures to reduce pressure on the environment. For example, for the coal industry, it is necessary to create a mechanism of "reverse" action in terms of simple maintenance of capacity, that is, to redistribute subsidies and production resource limits of production volumes prior to

${ }^{19}$ Energy Policy Scenarios to 2050, za: http://www.worldenergy.org /documents/ scenarios_study_online.pdf $(20.03 .2020)$ 
environmental measures for industrial wastes from mines and concentration plants ${ }^{20}$. The main condition for the formation of such an approach is not only the redistribution of limited financial resources in the interests of POST-COAL programs for the conservation of harmful emissions, but also the stimulation of production diversification in terms of managing production flows and waste., That is why the solution of theoretical and practical problems of modeling the interaction of these production flows as an ecological and economic subsystem in order to reduce their environmental load is the central problem of increasing the efficiency of modernization of the economy of post-Soviet countries.

\section{The methodology of quantitative assessment of energy stability in the conditions of modernization of post-soviet countries}

In the methodological aspect, a structured energy management scheme is a derivative of the evolution process that occurs using bifurcation diagrams. It these exact points there is a loss of stability in the socio-economic system and the formation of a state that determines the further strategy of modernization. Based on this, researchers concluded that the previous trajectory of the system with the bifurcation diagram has already lost stability, which is approaching catastrophic changes as a reaction to anthropogenic impact ${ }^{21}$.

These processes have been growing since 1991. At the same time, it is noted the possibility of a "rapid transformation" with minor external changes as well as a "critical slowdown" when many efforts do not lead to a noticeable change in the situation. Functional strategies include the environmental one as well, the formation of which takes place based on an assessment of the impact of "Post-coal" enterprises on the environment taking into account available technologies of coal extraction and processing. Additionally to environmentallyfriendly oriented enrichment technologies, the direction of sustainable development of the enterprises of the coal mining complex, namely coal mines, is possible due to the expansion of diversification output of minerals production, demanded by consumers. For example, in coal mining it is feasible to use mine methane, mine water heat, useful components of industrial waste. Building and decorative materials, bricks, special concrete components can be used in the domestic market ${ }^{22}$.

\footnotetext{
${ }^{20}$ World Energy Outlook 2013: IEA, za: http://www.worldenergyoutlook.org (25.03.2020)

${ }^{21}$ I.I. Pavlenko, O.V. Trifonova, Coal mine in the aspect of targeted investment, Academic look No. 2/2005, s. 62-66.

${ }^{22}$ S.M. Bugay, O.O. Kulik, Depressed regions: experience of the countries of the European Union, Coal market No. 2/2002, za: http: /Avww.epu.kiev.ua/All/2002/Q2/15.ht (2.04.2020)
} 
In addition, from a methodological point of view, the problem of the economical completeness of extracting mineral reserves or their losses cannot but taken into account the situation in the current specific conditions, with the prospects for the development of the industry and the state economy as a whole. Let us focus on the beginning of the long-term consequences of the loss of minerals. Before bringing the discussion on, it is important to clarify the concept of "long-term". Over the past ten years, long-term plans and forecasts generally did not go beyond the 20 -year period. Therefore, it seems very logical to consider as remote those consequences of the minerals loss that will occur in about the same period. It is reasonable to presume that alternative energy sources, capable of replacing coal, will develop and the technology of coal production itself, even if it is improved, will not fit into the life of future generations where technologies beyond our modern understanding prevail. Long-term consequences within a particular enterprise may be more significant. However, on many mines with sufficiently large reserves, a reduction in their validity period, for example, by 10 years, is also not particularly significant. Naturally, with a short residual life of an enterprise, its reduction due to significant losses is important and can serve as one of the motives for closing the mine earlier than planned. In the latter case, it is planned to remove the consequences of stock losses by less than 20 years, since this period will already be beyond the mine's existence ${ }^{23}$.

The solution of problems related to modernization of post-soviet countries is associated with the substantiation of optimal environmental management standards, the effective territorial distribution of industries, forecasting the consequences of human economic activity and other measures that will further determine the conditions for conducting business activities of individual enterprises. It is noted that one of the major shortcomings of economic activity is inability and unwillingness of people engaged in coal production to foresee the long-term consequences of their impact on nature (Fig. 1).

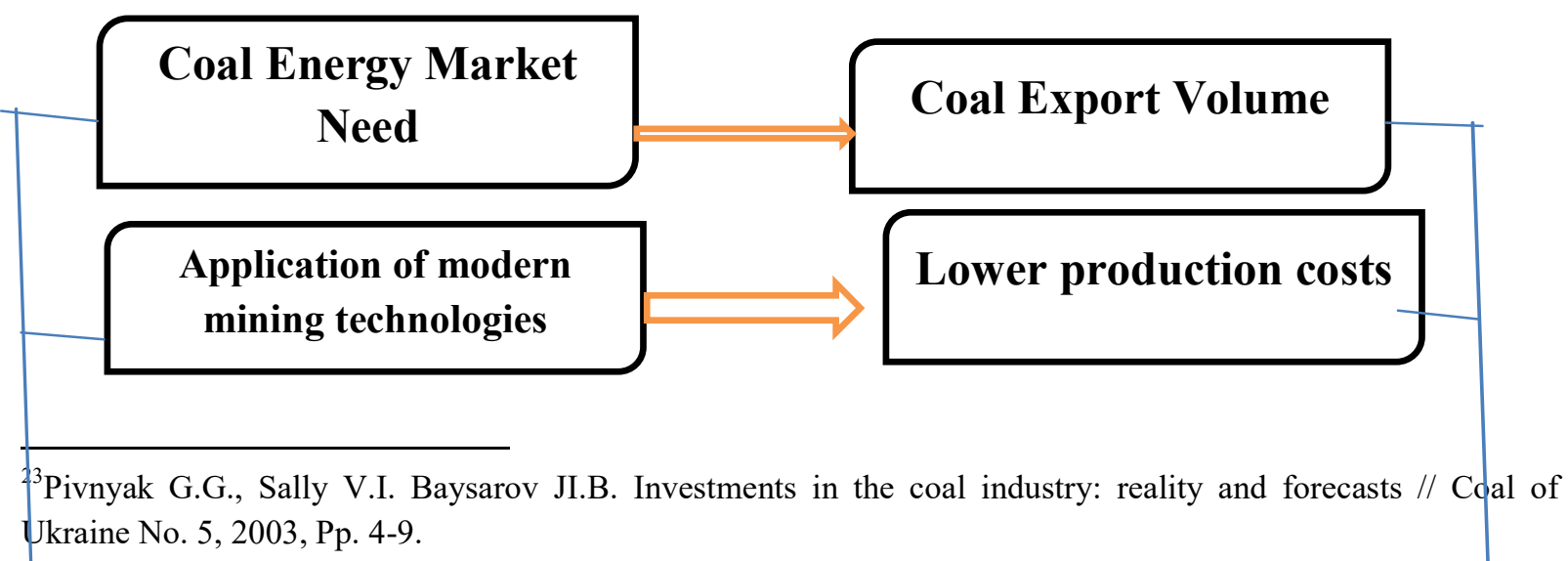




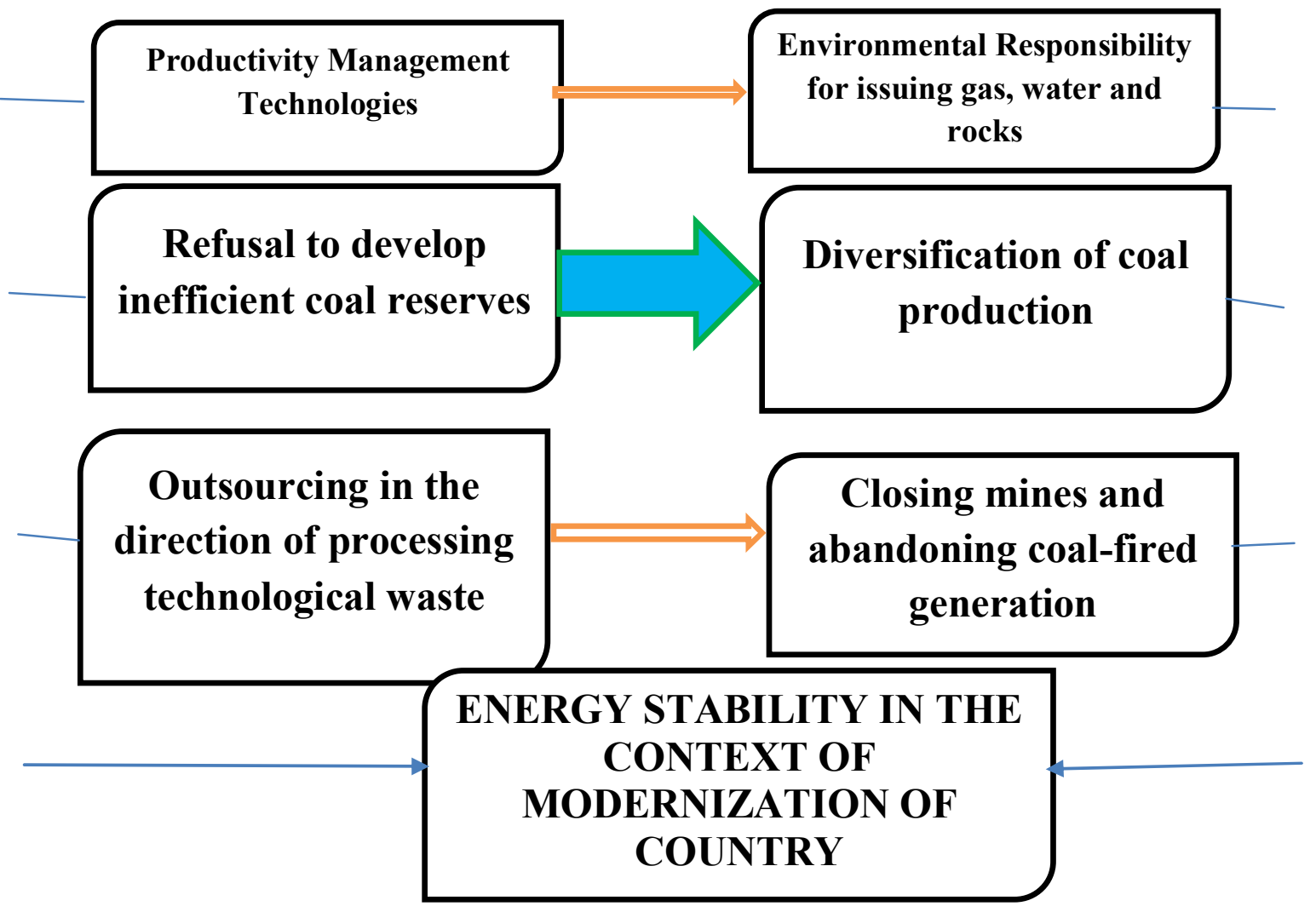

Fig. 1. Structural Energy Stability Scheme

Source: author's own study.

The elimination of these shortcomings is to improve the economic policy of environmental management, namely the basics of using individual economic instruments: payments (fees); prices duties; taxes depreciation insurance; loans, subsidies, etc. Thus, a complex mechanism is formed for influencing the economy of natural resource users for their incentive for rational nature management with the following alternatives for administrative regulation of activity: permission, restriction, prohibition.

The indicated characteristics of environmental management policy are genuinely important and relevant to ensure sustainable development of society, however, most of the instruments of influence are aimed to the enterprise which defines as direct natural resource user (removes the natural resource) and environmental pollutant, which should be fully responsible for the environmental and economic efficiency of the activity.

\section{Quantitative assessment of energy security level}

From the definition of the category "energy stability" it follows that it should contain a technological and economic component, combined in some way. In a modern sense of guaranteeing energy security - this is the achievement of a technically reliable, stable, cost- 
effective and environmentally balanced provision of energy resources to the needs of the economy and the population, as well as the creation of conditions for the formation and implementation of a policy to protect national interests in the energy sector ${ }^{24}$.

When carrying out the economic substantiation of investment projects regarding the potential of the industrial regions of Europe where coal was mined, there is no possibility to be guided by any norms or standards. At certain stages of the complex process of evaluating modernization of post-soviet countries, depending on the purpose and nature of reflections, specific mathematical methods and methods for obtaining optimal solutions can be used. Finding the best options for economic decisions should be based on a systematic approach and the use of decision theory.

One more important circumstance should be noted. At different times, diverse methodological principles were developed, allowing not only to evaluate the POST-COAL subsystems and their adequacy, but also to evaluate the quality of individual parameters, to form the degree of effectiveness and the system of restrictions in individual subsystems ${ }^{25}$. That is, purposefully manage the process of operational assessment of the quality of the technical and economic parameters of the development of enterprises of coal-mining regions at different stages of transformation (modernization). The basic principles of a comprehensive phased assessment of the results of modeling the development of modernization of post-soviet countries are reduced to the price of the level of natural parameters of a promising site, based on the determination of the specific volumes of application of basic technological schemes in each technological chain of a mining enterprise for the relevant conditions at the time of implementation of the decisions obtained in the model. A comprehensive indicator of the economic level of the POST-COAL subsystems is determined from the ratio of the sum of indicators that evaluate individual technological links (subsystems) of enterprises to diversify production. Further on, a feasibility study of design solutions is carried out on the basis of a set of criteria and separately for each criterion, both for the project as a whole and for the technological links and complexes of the coal and diversified enterprises ${ }^{26}$.

The main independent quality criteria in the feasibility study of the project may be the specific capital costs and the complexity of the production of diversification products. Using

\footnotetext{
${ }^{24}$ K.S. Zykov, Energy security as a component of economic development in Russia, International SPC "Economic and Energy Security of Russian Regions", Perm, 2003.

25 A.A. Rozhkov, Structural transformations in the coal industry and regions. World experience, problems, prospects, Collection of articles, LAP LAMBERT Academic Publishing, Saarbrücken 2015, s. 310.

${ }^{26}$ A.V. Zimakov, Is there a future for coal-fired power plants in Europe?, Bulletin of MGIMO University, No.5 (56)/2017, s. 150-159.
} 
these criteria, a comparative assessment of several investment projects can be performed. For this, the matrix of design indicators for all links is built. Each column of the matrix is an evaluation vector of the $j$-th solution (link) for the $i$-th project with the same set of criteria ${ }^{27}$. However, through various conditions for the reproduction of power (for the case of coal mining) and the operation of enterprises, the vectors are usually not comparable. Since the value of the evaluation criteria obtained in strictly individual mining and geological and other operating conditions of the mining enterprise and meets only these conditions, it should be reduced to a comparable form. The procedure for bringing indicators to a comparable form involves a transition from absolute to relative estimates ${ }^{28}$.

From among the given (dimensionless) indicators, it becomes possible to choose the base (best) values

$$
\begin{aligned}
& F_{j B}^{K}=\min _{i} F_{j i}^{K}, \text { at } K_{j} \rightarrow \min \\
& F_{j B}^{L}=\min _{i} F_{j i}^{L} \text {, at } L_{j} \rightarrow \min \\
& F_{j B}^{V}=\min _{i} F_{j i}^{L} \text {, at } V_{j} \rightarrow \min \\
& F_{j B}^{P}=\max _{j i}^{P} \text {, at } P_{j} \rightarrow \max ,
\end{aligned}
$$

where $K_{j}, L_{j}, V_{j}, P_{j}$ - design indicators, respectively, of specific investment, labor, cost and profit for the j-th evaluation unit; $; F_{j B}^{K}, F_{j B}^{L}, F_{j B}^{V}, F_{j B}^{P}$, - basic indicators, respectively, of specific investments, labor, cost and profit for the same link.

The further procedure involves the determination of the relative deviations of each indicator of the $\mathrm{i}$-th enterprise from the base value. In this case, the best solution is determined by the norm of the vector (the geometric sum of the relative deviations of the indicators of specific capital investments and labor intensity). In addition, for most mining enterprises decision-making problems should be resolved in the face of uncertainty, the cause of which is the existence of several options for economic activity or the need to distribute a limited number of production resources between several types of work, when the condition $\sum a\left\langle\sum b\right.$ is fulfilled, where $\mathrm{a}-$ available investment, $\mathrm{b}-$ the need for investment resources. In such cases, in order to minimize the risk of making decisions in the face of uncertainty and

\footnotetext{
${ }^{27}$ A.I. Amosa, M.A. Illiashov, V.I. Salli, Sistemny analiz shahti kak obiekta investirovania [System analysis of the mine as an object of investment], NAN Ukraine. Lnstitut ekonomiki promishlenosti, Donetsk 2002, s.68.

${ }^{28}$ A.G. Vagonova, Ekonomicheskie problem podderjania mosnosty ugolnih shaht Ukraine, Dnepropetrovsk 2005 s. 287.
} 
to obtain the maximum effect from the used resources, it is advisable to apply a methodology that combines both quantitative and qualitative methods, in particular based on rating and expert assessment methods ${ }^{29}$. The initial matrix of alternatives is presented in the form of a table in which $X i$ is an alternative, which can be, for instance, closure of mines, processing of industrial waste on the territory of coal-mining regions, and others. Criteria $K j$ indicates costs for the project; cost estimation of refusals from coal mining; reclamation costs and environmental protection measures; the impact of the project on the socio-economic situation in the region; the impact of the project on the state of labor resources, etc ${ }^{30}$.

Thus, one can track the increase in the priority of economic goals over environmental ones, and mining enterprises have a certain grace period to restore the stability of their own economic situation. This illustrates a dual approach to ensuring sustainable development of the territory:

- parity of economic and environmental goals to prevent negative externalities;

- the priority of economic development for the formation of a greater level of wealth over the financial and technological foundations of environmental restoration.

In this case, it is necessary to proceed from the assumption that the model is built for coal industry enterprises that are engaged in both coal mining and thermal energy production in the diversification mode of coal mining enterprises. This makes the proposed model universal to a sufficiently high degree. It is advisable to implement the model differentially according to alternative options for coal mining, energy and construction enterprises ${ }^{31}$.

It is well known that at any level the "POST-COAL" system is not closed; it always has a way out. Changes in operating conditions, the need for land restoration come to the input of subsystems and all components of enterprises from the external environment. Insufficiently accurate a priori knowledge of the initial parameters requires that for the purpose of analysis they are presented as some connected areas on the matrices that characterize the permissible values of each economic parameter ${ }^{32}$.

In the process of solving the problems of allocating investment resources, it is possible to minimize the probability of managerial errors when using criteria for assessing the

\footnotetext{
${ }^{29}$ M.P. Fedorov, V.R. Okorokov, Energy technologies and world economic development: past, present, future, Sankt Petersburg 2010, s.178.

${ }^{30}$ J. Saghir, Energy and Poverty Myths, Energy and Mining Sector Board, Energy Working Notes 2015.

${ }^{31}$ S.I. Melnikova, Decarbonization of European energy: goals and realities, Modern science: research, ideas, results, technologies, No. 2 (13)/2013, s.168-172.

${ }^{32}$ M. Anokhin, O. Grishin, Energy Safety: Politics and Diplomacy, Przeglad Strategiczny, №1/2013, s. 25-37.
} 
level of land restoration costs, the impact of industrial activity on the state of water, land and forest resources, as well as the impact of the project on the socio-economic situation in the region.

In accordance with this, the indicator "energy stability" consists of three elements (components): an indicator of the technological reliability of industries requiring energy resources $\alpha$, an indicator of the economic level of the state. In addition, the availability of mineral reserves is also important. The coefficient characterizing this quantity will be called the indicator of geological resources ${ }^{33}$. The values of the parameters were determined by comparing with suboptimal values of GDP per capita and energy consumption, the sufficiency level of own sources of primary energy, characterizes the possibility and feasibility of ensuring domestic energy consumption through additional supplies from outside the country, the ability of national production structures to effectively operate complex energy systems ${ }^{34}$. The choice of this integrated indicator is explained by the fact that a high level of economic development, literacy and education of the population makes it possible to compensate for the lack of own energy sources and ensure the efficient operation of complex energy production facilities.

For numerical source data, their interval tasks correspond to the situation with the greatest uncertainty. The ranges of permissible changes in the values of the resulting model indicators turn out to be, commonly, extremely wide. This drawback is partially eliminated, and the possibilities of quantitative, mathematical analysis of the initial data become much more reliable if, in addition to the interval estimation of the parameter, hypotheses are put forward on the form of the probability distribution functions for the realization of the parameter values in a given interval.

In some cases, the predominant application in the modeling of a particular mathematical apparatus may be associated with some formal circumstances. Such a formal, but substantial argument in favor of using as the degree of certainty of different opinions at intervals of initial parameters change modernization of post-soviet countries. The point is that the classification of resources that should inevitably be taken into account when assessing the

\footnotetext{
${ }^{33}$ S.A. Bakanov, The concept of "old industrial regions" in historical and economic research: problems of theory and historiography, Megastar Vitae: electronic journal on historical sciences and archeology, No. 24 (379) 2015, s. 160-167.

${ }^{34}$ Foy H. Eastern Europe to confront Berlin over new Russian gas pipeline, Financial Times. November 29 2015, za: http://www.ft.com/intl/cms/s/0/eb1ebca8-9514-11e5-ac15- 0f7f7945adba.html\#axzz3uylXlrdF (4.04.2020)
} 
competitiveness of finished products, is based on theoretical probabilities ${ }^{35}$. Since the project for the development of each section of a coal deposit or an industrial waste object is in many ways unique, it was recognized that when applying the theoretical probability of using traditional distribution averages ("mathematical expectation") of quantities that are adequate to mass phenomena when estimating reserves and calculating other resulting indicators repetitive is not always justified ${ }^{36}$. The results of technological studies and economic and mathematical modeling of processes allow us to examine in more detail the configuration and parameters of the restructuring and diversification systems of coal mining and processing enterprises, coordinate and determine the operating modes of subsystems operation and organization of production, predict technological and economic indicators of once again diversification production complexes.

\section{Conclusions}

To use the latest technologies for processing man-made deposits in difficult conditions, in particular with limited reserves and capacity, the theory of developing investment decisions should be able to reflect the relationship between different levels and subsystems of industry subordination, as well as taking into account market conditions, which dictates the level of demand and prices. It is possible to take into account these relations in investment projects by a combination of logical and mathematical methods. The systematic approach and all the methods of decision theory are valuable precisely because, based on a comparison of cost-effectiveness and results of these costs, as well as on the basis of decisionmaking methods, they make it possible to justify new optimal solutions in investment projects for the development of coal-mining regions.

Diversification of production as a form of organization of productive forces has attracted the attention, first of all, of coal production managers and environmentalists in connection with the demonopolization of the economy, the conversion of the militaryindustrial complex, and the expansion of competition. However, the economic science has not sufficiently studied the economic, technological and social aspects of the phenomenon. The theory could not foresee the emergence of many problems faced by enterprises of post-Soviet countries, having received the freedom to choose any type of activity that is not prohibited by

\footnotetext{
${ }^{35}$ O.A. Music, Bifurcations in nature and society: the natural science and socio-synergetic aspect, Modern high technology, No.1./2011, s. 87-91, za: http://www.top-technologies.ru/ru/article/view?id=26640 (4.04.2020)

36 A.A. Rozhkov, Structural transformations in the coal industry and regions. World experience, problems, prospects, Collection of articles, LAP LAMBERT Academic Publishing, Saarbrücken 2015, s. 310.
} 
law. This is especially true for mining enterprises. Therefore, any suggestions on the diversification of production in regions where inefficient coal mines remained and the transcendental ecological situation has formed can be considered a certain contribution to solving the problem of economical use of natural resources. Being a tool to eliminate imbalances in reproduction and redistribution of resources, the diversification of production and business activities has different goals and determines the direction of economic restructuring. Since neither domestic economic theory, nor empirical research provides us with sufficient information for analysis as the following statements are based on world experience known in Ukraine.

Thus, the protection of the economic interests of state enterprises consists in lobbying for corporate interests at institutional levels: regional and state. This scheme reflects the traditional three-format approach to determining the basis of social development: ecocentrism, technocentrism and moderation of the technogenic load. Fluctuations arising in society regarding the priority of one or another foundation distort the current economic conditions of coal enterprises and force them to reconsider economic strategies which affects their results.

The results of technological research and economic and mathematical modeling of processes allow us to examine in more detail the configuration and parameters of the restructuring and diversification systems of coal mining and processing enterprises, coordinate and determine the operating modes of control subsystems and organization of production, and forecast technological and economic indicators of modernization of postsoviet countries.

\section{Streszczenie:}

Przedmiotem niniejszego artykułu są zagadnienia metodologiczne i praktyczne zapewnienia zrównoważonego funkcjonowania systemów eliminacji szkodliwych skutków podziemnej eksploatacji węgla, gdyż węgiel stanowi prawie jedną czwartą całkowitej produkcji energii elektrycznej w UE. Celem jest kwantyfikacja propozycji dywersyfikacji produkcji w regionach, w których nadal istnieją nierentowne kopalnie węgla, stworzyła się zła sytuacja środowiskowa. Można to uznać za pewien wkład w rozwiązanie problemów modernizacji gospodarek krajów poradzieckich w zakresie spalania węgla. Produkcja oparta na węglu traci opłacalność ekonomiczną $\mathrm{z}$ powodu gwałtownego obniżania kosztów technologii zielonych, zaostrzania kontroli nad emisjami oraz wzrostu kosztów paliw kopalnych. W artykule uwaga została skupiona na parytecie celów ekonomicznych i środowiskowych w celu zapobiegania negatywnym zjawiskom zewnętrznym. Przy tym należy wyjść z założenia, że model ilościowej oceny jest budowany zarówno dla krajów zajmujących się wydobyciem węgla, jak i krajów zajmujących się produkcją ciepła w trybie dywersyfikacji przedsiębiorstw górniczych. Zaproponowano również kompleksowy wskaźnik 
stabilności energetycznej, wskazujący, że wysoki poziom rozwoju gospodarczego, umiejętności czytania i pisania oraz wykształcenia ludności pozwala w niezbędnym stopniu na zrekompensowanie braku własnych źródeł energii i zapewnienie efektywnych działań złożonych branż energetycznych.

\section{Słowa kluczowe:}

kraje górnicze, modernizacja gospodarki, dywersyfikacja, kwantyfikacja, diagram strukturalny, stabilność energetyczna, rozwój gospodarczy.

\section{Key words:}

coal-mining countries, economic modernization, diversification, quantification, block diagram, energy stability, economic development.

\section{Bibliografia:}

1. Abdi. H., Williams, L.J. Principal component analysis. Wiley Interdisciplinary Reviews: Computational Statistics 2010.

2. Amosha A.I., Skubenko V.P. The economic policy of the state and its impact on the activities of enterprises, Ekonomika promyslovosti, Donetsk 1EP HAH Ukraine, No.1/1997.

3. Amosa A.I., Illiashov M.A., Salli V.I (2002). Sistemny analiz shahti kak obiekta investirovania, System analysis of the mine as an object of investment, Monografia, NAN Ukraine. Lnstitut ekonomiki promishlenosti, Donetsk 2002.

4. .Astahov A.S., Dikolenko E.Y., Charshenko V.A. Ekologichesrata besopasnost i efektivnost prirodopolzovania, Environmental safety and environmental management, Gornaya kniga, izdatelstvo MGGU/ - 2009.

5. Anokhin M., Grishin O. Energy Safety: Politics and Diplomacy, Przeglad Strategiczny. No.1/2013.

6. Baitov A.V., Velikorossov V.V., Karjakin A.M. Russia's energy security in a market economy. 2012.

7. Bakanov S.A. The concept of "old industrial regions" in historical and economic research: problems of theory and historiography, Megastar Vitae: electronic journal on historical sciences and archeology. No. 24/2015.

8. Baeten G., Swyngedouw E., Albrechts L. Politics, Institutions and Regional Restructuring Processes: From Managed Growth to Planned Fragmentation in the Reconversion of Belgium's Last Coal Mining Region, Regional Studies, 1999.

9. Bardas A.V. Prinsipi ekologicheskoi pasportizacii ugledobuvnih pidpriimstv Ukraine $\mathrm{v}$ umovach pestrukturizacii galuzi, The principles of environmental certification of coal mining enterprises of Ukraine in the restructuring of the industry, D.Nationalny gorny university, 2010.

10. Bugay S.M., Kulik O.O. Depressed regions: experience of the countries of the European Union, Coal market, No. 2/2002. 
11. Cohen J. Why Russia may be a smart business partner for Israel, Reuters. February 23, 2016.

12. Communication from the Commission to the European Parliament and the Council. European Energy Security Strategy, Brussels. 28.05.2014.

13. Conerly B. Energy Forecast 2013-2014: Convert to Natural Gas, Forbes http://www.forbes.com/sites/billconerly/2012/10/26/energy-forecast2013-2014convert-to-natural-gas/

14. Drilling Market Focus: Chinese build rigs, drillers venture abroad, Oil \& Gas Journal. July 18 2015. Режим доступа: http://www.ogj.com/articles/print/volume-103/issue-27/drillingproduction/drillingmarket-focus-chinese-build-rigs-drillers-venture-abroad.html.

15. Energy Efficiency Plan 2011, Impact Assessment Annex II. — Brussels: European Commission, March 8, 2011. - (Commission Staff Working Document)

16. EU-Russian Energy Dialogue: The First Ten Years: 2000-2010 / European Commission DirectorateGeneral for Energy, Brussels, Belgium: European Union, 2011.

17. Energy Outlook 2030 (BP Global). http://www.bp.com/en/global/corporate/aboutbp/ statistical-review-of-world-energy-2013/ energy-outlook-2030.html.

18. Energy Policy Scenarios to 2050. źródło: http://www.worldenergy.org /documents/ scenarios_study_online.pdf.

19. Fedorov M.P., Okorokov V.R. Energy technologies and world economic development: past, present, future. - StP., 2010.

20. Foy H. Eastern Europe to confront Berlin over new Russian gas pipeline, Financial Times. November 29, 2015. http://www.ft.com/intl/cms/s/0/eb1 ebca8-9514-11e5ac15- 0f7f7945adba.html\#axzz3uylXlrdF

21. Frederic Gibou, Ronald Fedkiw A fast hybrid k-means level set algorithm for segmentation, In 4th Annual Hawaii International Conference on Statistics and Mathematics 2005.

22. Gas Exporting Countries Express Worry Over Market Volatility, Leadership. December 16, 2014, źródło: http://leadership.ng/business/395614/gas-exportingcountries-expressworry-market-volatility.

23. Gliszczynski G. Metodyka oceny jakosci procesow restrukturyzacji przedsiebiorstw górniczych, Gliszczynski G., Tomaszewski J., Paszcza H., Raport z realizacji projektu badawczego MNil. Lublin No. 4/2007.

24. Gryaznov L. Theses on energy crisis, Environmental systems, No. 2/2002.

25. Haghighi S.S. Energy security and the division of competences between the European Community and its member states // European Law Journal. 2008. Vol. 14. №4.

26. Hancher L., Ottervanger T., Slot P. EU State Aids. London, Sweet \& Maxwell, 2012.

27. Joseph Cortright Making sense of clusters: regional competitiveness and economic development, A Discussion Paper Prepared for the Brookings Institution Metropolitan Policy Program, March 2006.

28. 17. International Energy Agency. URL: https://www.iea.org/topics/energysecurity/ 
29. Kasper H., Etil B. V. The aftermath of the closure of the Dutch coal mines in South Limburg: Regional economic and social reconstruction. 2012 Available at: https://nowa-energia.com.pl/wpcontent/uploads/2013/03/raport_uniwersytet_w_maastricht_en.pd

30. Key World Energy Statistics 201. http://www.iea.org/Textbase/publications/ free_new_Desc.asp?PUBS_ID $=1199$

31. Key world energy statistics - 2016, International energy agency. https://www.iea.org/publications/freepublications/publication/key-world-energystatistics.html

32. Loehlin J.C. Latent variable models: An introduction to factor, path, and structural analysis, J.C. Loehlin. - Hillsdale, NJ: Lawrence Erlbaum, 2004.

33. Melnikova S.I. Decarbonization of European energy: goals and realities, Modern science: research, ideas, results, technologies. 2013. No. 2 (13).

34. Mezzetti M. Bayesian correlated factor analysis of socio-demographic indicators, M. Mezzetti, F.C. Billari. Statistical Methods \& Applications, No 14/2005.

35. Music O.A. Bifurcations in nature and society: the natural science and sociosynergetic aspect, Modern high technology, No. 1/2011, źródło: http://www.toptechnologies.ru/ru/article/view?id=26640 (accessed: 12/28/2019).

36. Pavlenko 1.1., Trifonova O.V. Vugilna mine in the aspect of targeted investment, Academic look., No. 2/2005.

37. Pivnyak G.G., Pilov P.I., Bondarenko V.I., Sally V.I. Internal reserves of increasing the efficiency of the coal industry in the conditions of market transformation of the Ukrainian economy. Mining Journal, Moscow, No.5/2005

38. Pivnyak G.G., Sally V.I. Baysarov JI.B. Investments in the coal industry: reality and forecasts, Coal of Ukraine No. 5/2003.

39. Regional policy of the EU countries, Ed. A.V. Kuznetsova. M .: Publishing House of the IMEMO RAS, 2009.

40. Rozhkov A.A. Structural transformations in the coal industry and regions. World experience, problems, prospects, Collection of articles. - Saarbrücken (Germany): LAP LAMBERT Academic Publishing, 2015.

41. Saghir J. Energy and Poverty Myths, Energy and Mining Sector Board, Energy Working Notes. 2015.

42. Sovacool B.K. Evaluating the Energy Security Impacts of Energy Policies, The Routledge handbook of energy security. Routledge 2011.

43. Statistical Review of World Energy June 2011, London: BP, 2011.

44. Tatarkin A.I., Kuklin A.A., Myzin A.L. Energy and economic security regions Russia, 2007.

45. Thompson B. Exploratory and confirmatory factor analysis: understanding concepts and applications, B. Thompson. - Washington: DCAPA, 2004.

46. The EU and Russia: our joint political challenge. Speech by Peter Man-delson. Bologna, $20 \quad$ April 2007, źródło: http://trade.ec.europa.eu/doclib/docs/2007/april/tradoc_134524.pdf .

47. Treaty of Lisbon. źródło: http://eur-lex.europa.eu/legalcontent/EN/TXT/?uri=celex\%3A12007L\%2FTXT 
48. Vagonova A.G. Ekonomicheskie problem podderjania mosnosty ugolnih shaht Ukraine, Economic problems of maintaining the capacity and investment of coal mines in Ukraine, Dnepropetrovsk: nationalny gorny universitet, 2005.

49. Verbeek J. J., Vlassis N., Kröse B. A k-segments algorithm for finding principal curves. Pattern Recognition Letters. No. 23/2002.

50. Voronchenok A.D., A.S. Tikhomirov, S.V. Skorodumov. Outsourcing of high technology to create new technology, 2006.

51. Witten I.H., Frank E., Hall M.A. Data Mining: Practical Machine Learning Tools and Techniques, 2011.

52. Zykov K.S. Energy security as a component of economic development in Russia, International SPC «Economic and Energy Security of Russian Regions», Perm 2003.

53. Zimakov A.V. Is there a future for coal-fired power plants in Europe?, Bulletin of MGIMO University, No. 5 (56)/ 2017. 